These machines were something. like the cutting-boxes used by farmers for chopping corn-stalks or straw for fodder. A box three or four feet long, a foot or more in width, and a foot in depth, was attached to an iron gearing which gathered in and twisted the hay. The heavy iron balance-wheels which were used on corn-shellers were easily adjusted to these mostly home-made machines. One person was required to turn the wheel, and another to feed the hay into the box, from which it was rapidly drawn into the iron gearing. The product was large clumsy coils of hay which were fed into and consumed by the big stoves. Prairie hay would buim down to a live coal, and so remain for some time, constantly giving out heat. And then it was both plenty and cheap. On some "blizzard days," however, it required lively work to keep a large house warm with this evanescent fuel. It is probable that prairie hay was utilized in this manner for several years, until the extension of railroads enabled the settlers to supply themselves with bituminous coal from the mines of central Iowa. And even now, whenever a coal famine is abroad, whether due to strikes of operatives, lack of transportation, or a snow blockade, corn and hay may again serve as winter fuel. In fact, we believe they are still so utilized in regions farther north.

\title{
DOCUMENTARY MATERIAL RELATING TO THE HISTORY OF IOWA.
}

Some four or five years ago Prof. B. F. Shambangh, of the Iowa State University, published the first of a series of . pamphlets with the above title. These pamphlets received a cordial welcome at once, though they did not escape the criticism that the "material" presented was already sufficiently accessible. This opinion was wholly incorrect. The pamphlets were made up from laws passed by Congress relating to the Old Northwest and the organization of terri- 
tories-the acts, resolutions and memorials of the Territorial legislatures of Ohio, Indiana; Wisconsin and Michigan. These various documents disclose the origin of local government, showing how a great region was governed before any subdivisions took place, and how territories were organized and governed until their own legislatures took that responsibility upon themselves. All this material existed and was "in books recorded," it is true, but was only accessible through great effort and at much expense. The plan adopted by Dr. Shambangh was to page these pamphlets for volumes of about 300 pages each. Two have now appeared and four to six are to follow. From the time that the first volume ap. peared the work has been widely quoted by historical students. When it is completed it will become one of the most valuable sources of western history. The thought which inspired this work was a happy one. Carried out to a successful conclusion, it will have a permanent and most important place in the historical literature of the Middle West.

Hon. James F. Wilson began his address before the makers of our present constitution, at the reunion in Des Moines, in the winter of 1882 , with the following philosophical statement of the importance of a study of the laws of a people in arriving at a clear understanding of their history:

Law is history. A substantially correct history of a people may be written from a copy of their laws. The philosophy of the world's movements may be read in the lines of the laws of the nations which have come and gone. Give the competent historian this data and he will put the nations of the past before you. The growth of a nation may be read in its laws. They tell us how it commenced, how it! progressed, what point of excellence it reached, when it faltered and how it failed. They tell us of its moral conditions, its degree of intelligence, its pursuits, its dominant

- thoughts, its characteristic traits. In the lines of its laws we read of its trade, its commerce, its occupations, its times of peace, its preparation for conflict, its victories and defeats. Inde'ed, the careful student of a nation's laws will arrive at a more correct knowledge of its real self than ordinarily comes from reading history as it is generally written. For the things which most nearly, practically and definitely affect a people are almost sure of a lodgment in their laws.

In investigating any or all these "points of history" the 
future student must have recourse to this great work, which will undoubtedly become sufficiently comprehensive to obviate the necessity of consulting original publications. The materials are exceedingly well edited, showing the sources whence they were derived. In fact, the importance of the work can scarcely be overestimated. He who reads State or Western history which is written after this time will learn from the multitude of references and quotations that in Shambangh's "Documentary Material" Senator Wilson's idea of the importance of studying the laws of a people to gain a knowledge of their history has been fully realized.

\section{GOVERNOR KIRKWOOD'S FIRST NOMINATION.}

Ralph P. Lowe succeeded James W. Grimes as Governor of Iowa in 1858. Mr. Lowe had served in the first Constitutional. Convention (1844), and in other useful and honorable positions. His name is often met with in the public journals of early Iowa. He had become so generally known and esteemed that he was easily nominated for the Governorship by the Republicans in 1857. In this high office be made an excellent record, and had the "piping times of peace" promised to continue he would undoubtedly have been renominated for a second term, in accordance with the political precedents of those days. Personally, he combined a gentle graciousness of manner with high dignity. He immediately placed every one who came into his presence at ease. He was a reliable and abiding friend, wherever his friendship was bestowed. His portrait in the capitol, from the easel of George H. Yewell, shows a most kindly face and one to be wholly trusted. How he would have succeeded had be become the "War Governor" of Iowa can at this time be but a matter of opinion, and opinions upon the subject. are not likely to be called out at this late day. Those, how- 
Copyright of Annals of Iowa is the property of State of Iowa, by \& through the State Historical Society of Iowa and its content may not be copied or emailed to multiple sites or posted to a listserv without the copyright holder's express written permission. However, users may print, download, or email articles for individual use. 